\title{
Primary HIV-I infection associated with pneumonitis
}

\author{
Edmund L.C. Ong and Bibhat K. Mandal
}

Regional Department of Infectious Diseases and Tropical Medicine, Monsall Hospital, Newton Heath, Manchester M10 8WR, UK

\begin{abstract}
Summary: A 21 year old homosexual man presented with an acute pneumonitis during symptomatic seroconversion for human immunodeficiency virus (HIV-I) infection. The symptoms resolved spontaneously without any therapeutic interventions needed. Acute pneumonitis should be added to the ever-increasing spectrum of clinical manifestations in primary HIV-I infection.
\end{abstract}

\section{Introduction}

The syndrome of primary human immunodeficiency virus (HIV-I) infection was first recognized in $1985^{1,2}$ and various mononucleosis-like, neuropathic and dermatological manifestations have been described since. We wish to report a case of a primary HIV-I infection associated with pneumonitis and thrombocytopenia.

\section{Case report}

A 21 year old homosexual man presented with a 10-day history of episodic breathlessness associated with a dry persistent cough, fever, chills and rigor, generalized aches and pains. He had been unwell for the past month with poor appetite, loss of weight of about $6 \mathrm{~kg}$ and loose bowel motions averaging 2 to 3 times per day. On examination he was febrile $39.9^{\circ} \mathrm{C}$, tachypnoeic; marked bilateral conjunctival injection and evidence of seborrhoeic dermatitis involving the face, trunk and upper limbs were noted. Respiratory examination showed a respiratory rate of $22 / \mathrm{min}$, peak expiratory flow of $410 / \mathrm{min}$ and bilateral fine late inspiratory crackles predominantly in the bases. Radial pulse was $100 / \mathrm{min}$, blood pressure 120 / $60 \mathrm{mmHg}$, jugular venous pressure $2 \mathrm{~cm}$ and heart sounds were normal. Investigations included haemoglobin $15.2 \mathrm{~g} / \mathrm{dl}$ (normal 13.0-18.0), white cell count $5.3 \times 10^{9} / 1\left(4.0-11.0 \times 10^{9} / 1\right)$ (neutrophils $3.5 \times 10^{9} / 1$, lymphocytes $1.3 \times 10^{9} / 1$, eosinophils $\left.0.5 \times 10^{9} / 1\right)$, platelets $63 \times 10^{9} / 1$ $\left(140-400 \times 10^{9} / 1\right)$ and plasma viscosity $148 \mathrm{cP}$ $(150-172)$. The Paul-Bunnell test was negative. The serum electrolytes, urea, creatinine, and liver

Correspondence: E.L.C. Ong, M.Sc., M.R.C.P. Accepted: 21 December 1990 function tests were all within normal range. On admission his blood gases on air were $\mathrm{pH} 7.45$ (7.36-7.45), $\quad \mathrm{PO}_{2} 60 \mathrm{mmHg} \quad(85-105), \quad \mathrm{PCO}_{2}$ $34 \mathrm{mmHg}(35-45)$, and on $28 \% \mathrm{O}_{2} \mathrm{pH} 7.45 \mathrm{PO}_{2}$ $90 \mathrm{mmHg}, \mathrm{PCO}_{2} 32 \mathrm{mmHg}$. The chest radiograph and electrocardiogram were normal. Induced sputum for microbiological screen including acidfast bacilli and Pneumocystitis carinii were negative and paired serology for respiratory viruses and atypical organisms were negative. The patient remained unwell with fever for 72 hours which settled spontaneously on the fourth day. On discharge the chest signs had completely resolved and the blood gases were $\mathrm{pH} \mathrm{7.43,} \mathrm{PO}_{2} 83.2 \mathrm{mmHg}$, $\mathrm{PCO}_{2} 33.2 \mathrm{mmHg}$ on air. The platelet count was $177 \times 10^{9} / 1$. He has remained well. Subsequent chest radiographs showed no abnormalities.

In view of his history the patient was counselled and consented to the HIV-I antibody test (ELISA and Western immunoblotting) which was negative on admission, but HIV-I proviral DNA was demonstrated by the polymerase chain reaction technique, p24 antigen was detected and HIV-I was subsequently cultured from the same serum. Serial weekly blood tests were done and 4 weeks later the $\mathrm{HIV}$ antibody test was positive. The $\mathrm{CD}_{4}$ count was $900 / \mathrm{mm}^{3}(500-1500)$.

\section{Discussion}

Primary HIV-I infection associated with pneumonitis has only been described once recently. It is likely that in our patient the symptoms of cough, breathlessness, and fever are in keeping with acute pneumonitis associated with the acute seroconversion illness of HIV-I as no other infective causes were found. Bronchoscopy with lavage and biopsy would have substantiated our case but the patient's symptoms resolved spontaneously with no other 
diagnostic and therapeutic interventions needed. Although the gastrointestinal manifestations of primary HIV-I infection are not common, diarrhoea and anorexia with weight loss as manifested in our patient have been reported. ${ }^{4}$ The presenting haematological abnormality of thrombocytopenia had been rarely reported. ${ }^{3}$

A T-lymphocyte alveolitis was observed in a majority of 276 HIV-I-infected patients who had cough and .breathlessness, interstitial pneumonitis and abnormalities of pulmonary function tests were documented in these patients. ${ }^{5}$ Whether the underlying mechanism is similar in primary HIV-I

\section{References}

1. Cooper, D.A., Gold, J., Maclean, P. et al. Acute AIDS retrovirus infection. Definition of a clinical illness associated with seroconversion. Lancet 1985, i: 537-540.

2. Ho, D.D., Sarngadharan, M.G., Resnick, L. et al. Primary human T-lymphotropic virus type III infection. Ann Intern Med 1985, 103: 880-883.

3. Kieff, E.D., Johnson, R.P. \& Mark, E.J. A 26-year-old woman with fever, diarrhoea, leukopenia, thrombocytopenia and hypoxaemia. N Engl J Med 1989, 321: 454-463. infection remains speculative. Our case demonstrates that physicians need to have a high index of suspicion of diagnosing HIV infection in patients who are at high risk and that acute pneumonitis should be added to the ever-increasing spectrum of clinical manifestations in primary HIV-I infection.

\section{Acknowledgement}

We thank Dr G. Corbett, North Manchester Regional Virus Laboratory, Booth Hall Children's Hospital, Manchester M9 2AA for performing the HIV assays.

4. Biggar, R.J., Johnson, B.K., Musoke, S.S. et al. Severe illness associated with the appearance of antibody to human immunodeficiency virus in an African. $B r$ Med $J$ 1986, 293: $1210-1211$.

5. Guillon, J.M., Autran, B., Denis, M. et al. Human immunodeficiency virus-related lymphocytic alveolitis. Chest 1988, 94: 1264-1270. 